\title{
The Effect of Integrated Movement Activities on Children's FMS
}

\author{
Shu-Chu Yang ${ }^{1}$, Shu-Jung Lin ${ }^{2, *}$, Li-Chuan $\mathrm{Hsu}^{3}$ \\ ${ }^{1}$ Department of Early Childhood Education, National ChiaYi University, Taiwan \\ ${ }^{2}$ Department of Early Childhood Education, Nanhua University, Taiwan \\ ${ }^{3}$ Department of Early Childhood Education, Chung Chou University of Science and Technology, Taiwan
}

Copyright $\bigcirc 2016$ by authors, all rights reserved. Authors agree that this article remains permanently open access under the terms of the Creative Commons Attribution License 4.0 International License

\begin{abstract}
The purpose of the present study was to determine the effects of an integrated movement course on the FMSs of preschool children. Purposive sampling was used to select two classes at a public preschool in Chiayi City, Taiwan. The experimental group consisted of 9 boys and 12 girls, and the control group consisted of 11 boys and 8 girls. Both were administered a pretest and a posttest. There were 5 results as follows: 1. For LS, the experimental group $(M=32.38)$ performed better than the control group $(M=23.53)$. For OCS, the posttest revealed no significant difference between the two groups. 2. The experimental group performed better than the control group in running $(t=2.23, P<.05)$, galloping $(t=8.09, P<.001)$, leaping $(t=2.96, P<.01)$, and horizontal jumping $(t=2.96, P<.01)$. 3 . There was a significant difference between the pre- and posttests of the experimental group in running $(t=-3.05$, $P<.01)$, galloping $(t=-7.90, P<.001)$, hopping $(t=-5.19$, $P<.001)$, jumping $(t=-2.31, P<.05)$, dribbling $(t=-2.71$, $P<.05)$, throwing $(t=-3.99, P<.01)$, and rolling $(t=-3.47$, $P<.01)$, indicating improvement in each of these seven skills. 4. For the control group, there was a significant difference between the pre- and posttests only for sliding $(t=-2.88, P<.05)$; even though they didn't participate in the integrated movement course, their sliding ability improved. 5 . The experimental group performed better in the posttests for both the LS $(M=32.31>M=24)$ and the OCS $(M=25.71>M=18.81)$. This indicates that the integrated movement course had a positive influence on both the LS and OCS of the experimental group.
\end{abstract}

Keywords Integrated Movement Activities, The Integrated Physical Education course, FMS

\section{Introduction}

Fundamental movement skills(FMSs) can be categorized into locomotor skills and object control skills. Childhood is the ideal time for developing FMS, yet teachers need to keep in mind the developmental limitations of their students when planning and selecting interesting activities which are challenging, but not beyond their ability [1,2]. Moreover, the development of FMSs is deeply influenced by a child's everyday interactions with others, especially parents, teachers, and playmates. Thus parents and teachers need to provide an environment and plan activities which promote the acquisition of FMSs $[1,3]$.

Over 80 percent of preschools in Taiwan have a curriculum which includes games and activities designed to develop physical skills. However, most of these are held only once a week, and few run for more than 40 minutes per session [4]. This indicates that preschools don't give sufficient importance to the development of FMSs, and that educators lack knowledge and ability in this respect [5].

Huang and Huang [6] assert that physical education classes in Taiwan are not sufficiently systematic. Ho and Lou [7] found that most of the physical education (PE) activities at preschools are in the form of group games in which the children spend most of their time passively waiting for their turn or for the game to conclude after being eliminated from the competition. Even when the teacher makes an effort to arrange activities which require continuous participation on the part of all the students, it often happens that the more physically developed students dominate the activity, pushing the less developed ones to the sidelines. Thus teachers need to plan activities which students enjoy and which require everyone to actively participate.

Based on my two decades of experience in early childhood education, very few preschools in Taiwan provide systematic PE classes. This may be because teachers lack training in the physical development of children. Or it may be due to teachers not having enough time to plan more suitable activities, instead falling back on such traditional routines as morning calisthenics and recess on the outdoor playground. In fact, the game most commonly played at preschools in Taiwan tend to be chosen because they are fun or competitive, but if not systematically planned, many such activities have little value with respect to the development of FMSs.

Amongst the related studies carried out in Taiwan during 
the past decade, few refer to the empirical research previously carried out on the development of FMSs [8]. Huang, Chou, Cheng, and Lin [9] and Shih et al. found that a six-week physical education course enhanced the acquisition of FMSs amongst preschoolers [8]. Similarly, Tsai conducted a 40-minute physical education class for preschoolers twice a week for six weeks, and found that by the end of the course the participants had significantly improved in running, galloping, horizontal jumping, and sliding [10].

Similarly, Chiu [11] found that preschoolers who had completed a 12-week physical education course had significantly better scores on the Test of Gross Motor Development-2 (TGMD-2). Also, Barid et al. [12] designed and conducted a one-hour FMS course twice per week over a span of ten weeks, and found that by the end of the course the participants' FMSs had improved significantly.

In the empirical studies mentioned above, most of the physical education courses continued for between six and twelve weeks, with classes being held twice a week for between 40 minutes and one hour. Although the Temporary Guidelines for Preschool Activities recently adopted by Taiwan's Ministry of Education (MOE) stresses the integration of the different components of the curriculum [13], none of these previous studies attempted to integrate the PE course into the existing curriculum. Therefore, the purpose of the present study was to determine the effects of an integrated movement course on the FMSs of preschool children. It is expected that the results of this study can be used in the design and implementation of preschool curriculums which place more stress on the acquisition of FMSs in an enjoyable manner.

\section{Methodology}

\subsection{Participants}

Purposive sampling was used to select two classes at a public preschool in Chiayi City, Taiwan. Each class had a total of 28 children. All of the children were between four and five years old and in good health. One class was designated the experimental group and the other was designated the control group. Both were administered a pretest and a posttest. Of the initial 56 participants, 16 did not participate in all phases of the study; thus only the data for the remaining 40 participants was included in the data analysis. The experimental group consisted of 9 boys and 12 girls, and the control group consisted of 11 boys and 8 girls. At the time the pretest was administered the average age of the participants was four years and one month; at the time of the posttest the average age of the participants was four years and four months. The participants in the experimental group had an average height of 106.5 centimeters and an average weight of 18 kilograms; the participants in the control group had an average height of 106.8 centimeters and an average weight of 17.6 kilograms.

\subsection{Measures}

FMSs were measured using TGMD-2, a widely used test developed in the United States by Ulrich and Sanford [14] . Locomotor skills(LS) can be categorized into run, gallop, hop, leap, horizontal jump, and slide. Object control skills(OCS) can be categorized into striking a stationary ball, stationary dribble, kick, catch, overhand throw, and underhand roll. Each skill included between three and five performance criteria which were scored as either 1: Present or 0: Absent in two trials. Scores for each child were calculated by totaling the number of correct performances for each skill (e.g., sliding consists of four performance criteria, so the score range was 0-8) The maximum subtest score is 48 for both locomotor skills (LS)and object control skills(OCS), with a minimum of zero. The sum of these subtests yields the total score (total FMS).

\subsection{The Integrated Physical Education Course}

The teacher of the experimental group integrated the 12 movement skills of the TGMD-2 into the existing curriculum. Each skill was practiced for half an hour, three times over the course of one week. Each 30-minute session was divided into five minutes for warm-up exercises, 20 minutes for the main activity, and five minutes for cooling down. During the warm ups the teacher played recorded music. The main activity consisted of three gross motor activities related to a single skill (running, hopping, leaping, dribbling, throwing, etc.) designed by the teacher to be simple yet interesting.

\subsection{Procedures}

After selecting the preschool, I contacted the director and explained the purpose of the study and the procedures to be used. Prior to testing, I contacted the participating teachers and explained their role in the research, including the testing procedures and the parental consent forms. The teacher of the experimental group integrated each of the 12 FMSs into the existing curriculum; she also participated in the meetings held by the research team every two weeks over the course of the study to discuss the progress of the research and any problems which had arisen. The teacher of the control group administered the pre- and posttests and conducted the existing PE classes without making any modifications. Both the pre- and posttests were videotaped for the purpose of scoring and discussion.

A Sony DV camcorder was used to film the testing sessions. The evaluations of each participant's performance were carried out by using Windows Media Player to play back the recordings at a slow speed and checking the appropriate spaces on the evaluation forms. The evaluations were carried out by four research assistants with extensive experience using the TGMD-2; each had previously carried out at least 500 such evaluations. 


\subsection{Data Analysis}

A dependent sample $t$-test was used to compare the differences between the pre- and posttest scores of each group. An independent sample $t$-test was used to compare the scores of the two groups of participants.

\section{Results}

Table 1 shows that the pretest revealed no significant difference between the two groups in both locomotor skill (LS) $(t=1.03, P>.05)$ and object control skill (OCS) $(t=$ -.65, $P>.05$ ). Table 1 also shows that for LS there was a significant difference between the pre- and posttests of the experimental group $(t=6.87, P<.001)$, and that the experimental group $(M=32.38)$ performed better than the control group $(M=23.53)$. For OCS, the posttest revealed no significant difference between the two groups $(t=1.23$, $P>.05)$. However, in the pretest the experimental group had a lower score in OCS than the control group, but in the posttest the experimental group scored somewhat higher than the control group.

Table 1. The LS and OCS of the experimental groups (eg) and control groups (cg).

\begin{tabular}{cccccc}
\hline Item & Group & No. & Mean & SD & $t$ \\
\hline $\begin{array}{c}\text { LS } \\
\text { pretest }\end{array}$ & eg/cg & $21 / 19$ & $24 / 22.31$ & $6.58 / 3.37$ & 1.03 \\
\hline $\begin{array}{c}\mathrm{CS} \\
\text { pretest }\end{array}$ & $\mathrm{eg} / \mathrm{cg}$ & $21 / 19$ & $18.8 / 20.1$ & $4.95 / 7.00$ & -.65 \\
\hline $\begin{array}{c}\mathrm{LS} \\
\text { posttest }\end{array}$ & $\mathrm{eg} / \mathrm{cg}$ & $21 / 19$ & $32.38 / 23.53$ & $4.66 / 3.29$ & $6.87 * * *$ \\
\hline $\begin{array}{c}\text { OCS } \\
\text { posttest }\end{array}$ & $\mathrm{eg} / \mathrm{cg}$ & $21 / 19$ & $25.71 / 23.16$ & $7.70 / 5.08$ & 1.23 \\
$* * * P<.001$ & & & & &
\end{tabular}

Table 2 shows that there was a significant difference between the posttests of the experimental and control groups in running $(t=2.23, P<.05)$, galloping $(t=8.09, P<.001)$, leaping $(t=2.96, P<.01)$, and horizontal jumping $(t=2.96$, $P<.01)$. In each of these LS the experimental group performed better than the control group: $M=7.14>6.63$, $5.9>2.21,4.14>3.05$, and $5.76>3.52$, respectively.

Table 2. The results of the posttests of the experimental and control groups in each LS.

\begin{tabular}{cccccc}
\hline Item & Group & No. & Mean & SD & $t$ \\
\hline $\begin{array}{c}\text { Running } \\
\text { posttest }\end{array}$ & $\mathrm{eg} / \mathrm{cg}$ & $21 / 19$ & $7.14 / 6.63$ & $.910 / .50$ & $2.23^{*}$ \\
\hline $\begin{array}{c}\text { Galloping } \\
\text { posttest }\end{array}$ & $\mathrm{eg} / \mathrm{cg}$ & $21 / 19$ & $5.9 / 2.21$ & $1.37 / 1.51$ & $8.09^{* * *}$ \\
\hline $\begin{array}{c}\text { Hopping } \\
\text { posttest }\end{array}$ & $\mathrm{eg} / \mathrm{cg}$ & $21 / 19$ & $6.14 / 5.26$ & $1.77 / 1.45$ & 1.71 \\
\hline $\begin{array}{c}\text { Leaping } \\
\text { posttest }\end{array}$ & $\mathrm{eg} / \mathrm{cg}$ & $21 / 19$ & $4.14 / 3.05$ & $1.28 / 1.03$ & $2.96^{* *}$ \\
\hline $\begin{array}{c}\text { Horizontal } \\
\text { jumping } \\
\text { posttest }\end{array}$ & $\mathrm{eg} / \mathrm{cg}$ & $21 / 19$ & $5.76 / 3.52$ & $1.92 / .90$ & $4.63^{* * *}$ \\
\hline $\begin{array}{c}\text { Sliding } \\
\text { posttest }\end{array}$ & $\mathrm{eg} / \mathrm{cg}$ & $21 / 19$ & $3.28 / 2.84$ & $2.03 / 1.21$ & .83 \\
\hline
\end{tabular}

***P<.001, $\quad * * P<.01, * P<.05$

Table 3 shows that there was a significant difference between the pre- and posttests of the experimental group in running $(t=-3.05, P<.01)$, galloping $(t=-7.90, P<.001)$, hopping $(t=-5.19, P<.001)$, jumping $(t=-2.31, P<.05)$, dribbling $(t=-2.71, P<.05)$, throwing $(t=-3.99, P<.01)$, and rolling $(t=-3.47, P<.01)$, indicating improvement in each of these seven skills.

Table 3. Comparison of the experimental group's pre- and posttests in LS and OCS.

\begin{tabular}{|c|c|c|c|c|}
\hline item & No. & Mean & SD & $t$ \\
\hline $\begin{array}{c}\text { Running pretest / } \\
\text { posttest }\end{array}$ & 21 & $6.19 / 7.14$ & $1.17 / 0.91$ & $-3.05 * *$ \\
\hline $\begin{array}{c}\text { Galloping pretest / } \\
\text { posttest }\end{array}$ & 21 & $2.52 / 5.90$ & $1.33 / 1.37$ & $-7.90 * * *$ \\
\hline $\begin{array}{c}\text { Hopping pretest / } \\
\text { posttest }\end{array}$ & 21 & $3.33 / 6.14$ & $2.08 / 1.77$ & $-5.19 * * *$ \\
\hline $\begin{array}{l}\text { Leaping pretest / } \\
\text { posttest }\end{array}$ & 21 & $4.00 / 4.14$ & $2.17 / 1.28$ & -0.40 \\
\hline $\begin{array}{c}\text { Horizontal jumping } \\
\text { pretest / posttest }\end{array}$ & 21 & $4.62 / 5.76$ & $2.11 / 1.92$ & $-2.31 *$ \\
\hline $\begin{array}{l}\text { Sliding pretest / } \\
\text { posttest }\end{array}$ & 21 & $3.33 / 3.29$ & $2.76 / 2.03$ & 0.07 \\
\hline $\begin{array}{c}\text { Striking pretest / } \\
\text { posttest }\end{array}$ & 21 & $3.43 / 4.43$ & $1.72 / 2.58$ & -1.62 \\
\hline $\begin{array}{c}\text { Dribbling pretest / } \\
\text { posttest }\end{array}$ & 21 & $2.67 / 3.90$ & $1.62 / 1.73$ & $-2.71 *$ \\
\hline $\begin{array}{l}\text { Catching pretest / } \\
\text { posttest }\end{array}$ & 21 & $2.71 / 3.14$ & $1.31 / 1.85$ & -1.04 \\
\hline $\begin{array}{l}\text { Kicking pretest / } \\
\text { posttest }\end{array}$ & 21 & $4.86 / 5.48$ & $0.91 / 1.47$ & -1.94 \\
\hline $\begin{array}{c}\text { Throwing pretest / } \\
\text { posttest }\end{array}$ & 21 & $2.76 / 4.52$ & $2.23 / 2.50$ & $-3.99 * *$ \\
\hline $\begin{array}{l}\text { Rolling pretest / } \\
\text { posttest }\end{array}$ & 21 & $2.38 / 4.24$ & $1.80 / 2.14$ & $-3.47 * *$ \\
\hline
\end{tabular}

Table 4. Comparison of the control group's pre- and posttests in LS and OCS.

\begin{tabular}{|c|c|c|c|c|}
\hline item & No. & Mean & SD & $t$ \\
\hline $\begin{array}{c}\text { Running pretest / } \\
\text { posttest }\end{array}$ & 19 & $6.58 / 6.63$ & $0.77 / 0.50$ & -0.25 \\
\hline $\begin{array}{c}\text { Galloping pretest / } \\
\text { posttest }\end{array}$ & 19 & $2.42 / 2.21$ & $1.35 / 1.51$ & 1.71 \\
\hline $\begin{array}{l}\text { Hopping pretest / } \\
\text { posttest }\end{array}$ & 19 & $4.89 / 5.26$ & $1.76 / 1.45$ & -0.89 \\
\hline $\begin{array}{l}\text { Leaping pretest / } \\
\text { posttest }\end{array}$ & 19 & $\begin{array}{c}3.26 / \\
3.05\end{array}$ & $1.33 / 1.03$ & 0.78 \\
\hline $\begin{array}{c}\text { Horizontal jumping } \\
\text { pretest / posttest }\end{array}$ & 19 & $\begin{array}{c}3.26 / \\
3.53\end{array}$ & $1.73 / 0.90$ & -0.84 \\
\hline $\begin{array}{l}\text { Sliding pretest / } \\
\text { posttest }\end{array}$ & 19 & $\begin{array}{c}1.89 / \\
2.84 \\
\end{array}$ & $1.20 / 1.21$ & $-2.88^{*}$ \\
\hline $\begin{array}{c}\text { Striking pretest / } \\
\text { posttest }\end{array}$ & 19 & $3.63 / 3.95$ & $2.19 / 1.78$ & -0.55 \\
\hline $\begin{array}{c}\text { Dribbling pretest / } \\
\text { posttest }\end{array}$ & 19 & $3.05 / 3.63$ & $2.27 / 1.42$ & -1.07 \\
\hline $\begin{array}{c}\text { Catching pretest / } \\
\text { posttest }\end{array}$ & 19 & $2.32 / 2.79$ & $1.53 / 1.62$ & -0.98 \\
\hline $\begin{array}{c}\text { Kicking pretest / } \\
\text { posttest }\end{array}$ & 19 & $5.00 / 5.00$ & $1.53 / 1.00$ & 0.00 \\
\hline $\begin{array}{c}\text { Throwing pretest / } \\
\text { posttest }\end{array}$ & 19 & $3.05 / 3.74$ & $2.15 / 1.66$ & -0.97 \\
\hline $\begin{array}{c}\text { Rolling pretest / } \\
\text { posttest }\end{array}$ & 19 & $\begin{array}{c}3.00 / \\
4.05 \\
\end{array}$ & $2.56 / 1.75$ & -1.44 \\
\hline
\end{tabular}


Table 4 shows that for the control group there was a significant difference between the pre- and posttests only for sliding $(t=-2.88, P<.05)$; even though they didn't participate in the integrated movement course, their sliding ability improved.

Table 5 shows that the $t$-test revealed a significant difference between the experimental group's pre- and posttest scores for both the $\operatorname{LS}(t=-6.36, P<.001)$ and the OCS $(t=-4.73, P<.001)$. However, no significant difference was found between the control group's pre- and posttest scores for the LS $(t=-1.61, P<.05)$ and the OCS $(t=-1.78$, $P>$.05). It can also be seen that the experimental group performed better in the posttests for both the $\operatorname{LS}(M=32.31$ $>M=24)$ and the OCS $(M=25.71>M=18.81)$. This indicates that the integrated movement course had a positive influence on both the LS and OCS of the experimental group.

Table 5. The pre- and posttests of the experimental groups and control groups inLS and OCS.

\begin{tabular}{ccccc}
\hline Item & No. & Mean & SD & $t$ \\
\hline $\begin{array}{c}\text { LS pretest } \\
(\mathrm{eg} / \mathrm{cg})\end{array}$ & $21 / 19$ & $24 / 22.32$ & $6.58 / 3.37$ & $-6.36 * * * /-1.61$ \\
\hline $\begin{array}{c}\text { LS } \\
\text { posttest } \\
(\mathrm{eg} / \mathrm{cg})\end{array}$ & $21 / 19$ & $32.31 / 23.53$ & $4.66 / 3.29$ & \\
\hline $\begin{array}{c}\text { OCS } \\
\text { pretest } \\
(\mathrm{eg} / \mathrm{cg})\end{array}$ & $21 / 19$ & $18.81 / 20.05$ & $4.95 / 7.00$ & $-4.73 * * /-1.78$ \\
\hline $\begin{array}{c}\text { OCS } \\
\text { posttest } \\
(\mathrm{eg} / \mathrm{cg})\end{array}$ & $21 / 19$ & $25.71 / 23.16$ & $7.70 / 5.05$ & \\
\hline$* * * P<.001$, & $* * P<.01$ & & & \\
\hline
\end{tabular}

\section{Discussion and Conclusions}

Research has shown that the conventional approach to preschool PE classes does promote the development of FMSs. However, integrating movement activities into the overall curriculum brings about better results.

In light of the long working hours and heavy workload of preschool teachers in Taiwan [15], they are sure to find it difficult to participate in a comprehensive and systematic training course in fundamental movement skill education. As for teachers at public preschools, the most suitable time for conducting such training would be during the winter and summer vacations. As for teachers at private preschools, the training could be carried out on six consecutive Saturdays. The course might include movement theory; training in the 12 movement skills of the TGMD-2; how to turn them into activities and games which are lively and fun; and how to make the activities more interesting by integrating music and other materials.

Taiwan's university programs in early childhood education do include courses in games and physical education. However, since students take these courses in their sophomore or junior years, and since there is usually a considerable gap between graduation and landing a teaching position, by the time they actually begin teaching at a preschool, most have already forgotten the bulk of what they learned in these two courses.

Once they begin teaching, the preschool expects them to focus on teaching, course design, taking care of the children, etc. Moreover, some preschools appoint specialized physical education teachers to come once or twice per week to conduct activities which are unrelated to those being taught by the full-time teachers. Also, few preschool teachers design physical education classes, and even if they do, the class is unlikely to link up with the activities already being taught. Actually, preschool teachers have little time available for planning additional activities, and the professional training provided to them by preschools doesn't give much emphasis to physical education. Thus it is important to provide preschool teachers with adequate training in the design and implementation of gross motor activities.

Thus it is suggested that preschool teachers participate in school, government, and civic training programs focusing on the design of lively and challenging activities which promote the development of FMSs, and how to integrate them into the school day. By doing so, their students will acquire FMSs more efficiently and enjoyably, and also be more confident as when they enter elementary school.

\section{REFERENCES}

[1] Li, C., \& Chang, H. C.(2006). Explore the factors that influence children to participate the leisure activities. Taiwan Education Review, 642, 43-47.

[2] Chang, H. C., \& Chen, J. F. (2012). Fostering Children's Regular Exercise Behavior-An Social Ecological Perspective. Journal of Professional Teachers, 3, 1-14.

[3] Shenouda, N., Gabel, L., \& Timmons, B.W. (2011). Preschooler focus-physical activity and motor skill development. Child Health \& Exercise Medicine Program, Issue 3.

[4] Chen, H. Y., \& Huang, Y. K. (2005). Results of the Survey of Children's Games in Taiwan. Child Sports Game Annals, 1,9-27.

[5] Weikart, P. S. (2009). Round the circle: Key experiences in movement for children. (Yang Shu Chu Trans.). Taipei: Psychological Publishing(original publish 1987).

[6] Huang, Y. K., \& Huang, Y. W.(2003). Thoughts and Development Strategies for Sports Population Doubling Plans for Childrn. National Sports Quarterly, 32(2), 48-52.

[7] Ho, W. H., \& Lou, Y. C. (2000). Sports Activities without [Loser] but Only with [Winner]-Application of Motion Education in Child Physical Ability Program. Journal of Chia Institute of Technology,20,100-111.

[8] Shih, K. T., Huang, H. C., Huang, M. Y., \& Lin, H. H.(2006). Using of Movement Skill Program into Physical Education on Motor Skill Performance of Preschool Children. Tpec Press, 14, 36-47. 
[9] Huang, H. C., Chou, C. C., Cheng, C. Y., \& Lin, C. W.(2005). The Impact of Intervention of a Motor Skills Program on Preschool Children's Fundamental Motor skills and cognition of movement concept. Research Quarterly for Exercise and Sport, 76(1), A77-A78.

[10] Tsai, S. J.(2010). The Effects of Movement Education Program on the Locomotor Movement skills for young children. Unpublished master's thesis, National Taipei University of Education, Taipei, Taiwan.

[11] Chiu, W. C.(2013). Studies of sport education integrated into early childhood's physical curriculum that affects their motor skills. Unpublished master's thesis, National Kaohsiung Normal University, Kaohsiung.
[12] Bardid, F., Deconinck, F. J. A., Descamps, S., Verhoeven, L., Pooter, G. D., Lenoir, M., \& Bouchard, C., Blair, S.N., \& Haskell, W. L. (2007). Physical activity and health. Champaign, IL: Human Kinetics.

[13] Ministry of education (2013). Preschool's Curriculum Interim Outline. Taipei: Ministry of education.

[14] Ulrich, D.A., \& Sanford, C. B. (2000). TGMD-2 : test of gross motor development: examiner's manual (2nd ed.). Austin TX: PRO-ED.

[15] Chen, K. T.(2003). Research on the preschool teachers' perceived problems and coping strategy. Journal of Child Care, 1,185-213. 